\title{
History of Ukrainian Philosophy: Teaching and Evaluation Methodology
}

\author{
Sergii Rudenko \\ Doctor of Philosophical Sciences, Associate Professor, \\ Taras Shevchenko National University of Kyiv \\ (Kyiv, Ukraine) \\ E-mail: rudenkosrg@gmail.com \\ ORCID: 0000-0001-9069-0989
}

This paper presents the author's methodology for teaching the History of Ukrainian Philosophy for students of the Taras Shevchenko National University of Kyiv as well as a methodology for evaluating learning outcomes based on a competence approach. The author has formulated eight key competences in the field of History of Ukrainian Philosophy, which are used to formulate the content model of the training course, as well as evaluation the results of students'study of the History of Ukrainian Philosophy. The Evaluation principles are represented through the two groups. The first group describe historiographical abilities whereas the second one reflects abilities concerning the rational reconstruction. Combination of these two groups of competencies makes the Evaluation Methodology clear, flexible and representative.

The paper proposes an expanded content model of the course on History of Ukrainian Philosophy, which is based on author's research in the field of historiography of Ukrainian philosophy and methodology of the study of the History of Ukrainian philosophy.

Keywords: History of Ukrainian Philosophy; Teaching Methodology; Evaluation Methodology; Higher Education; Ukrainian culture

Received: July 27, 2018; accepted: September 3, 2018

Future Human Image, Volume 10, 2018: 85-91.

DOI: $10.29202 / \mathrm{fhi} / 10 / 9$

\section{Introduction}

Studying the history of Ukrainian philosophy is an important part of the educational process in the system of higher education of Ukraine. However, the teaching of the History of Ukrainian philosophy has no systematic implementation, since at present there is no educational standard for teaching this discipline. In most cases, the History of Ukrainian philosophy at Ukrainian Universities is taught as a historiography of philosophical ideas in Ukrainian culture, or based on the results of scientific studies of a particular teacher. This creates a certain imbalance in understanding the content of this discipline, the methods of teaching and evaluation. This imbalance is useful for a research system; however, it is harmful to educational practice.

(C) Rudenko, Sergii, 2018 
In our opinion, solving this problem is possible through a certain standardization of the teaching of the history of Ukrainian philosophy for University students. It should be noted that standardization does not imply unification and uniformity in the teaching of the History of Ukrainian Philosophy. In our opinion, the creation of the standard of teaching the history of Ukrainian philosophy is to determine the set of minimum requirements for the teacher and students. These requirements could be formulated most effectively and clearly, in the form of competencies and learning outcomes, which is the key objective of this article.

In developing the methodology for teaching and assessing the history of Ukrainian philosophy, the author relied on the research of Ivan Ogorodnyk and Myroslav Rusyn [History of Ukrainian Philosophy, 2008], Tomasz Mróz [Mróz, 2016], Serhii Yosypenko [Yosypenko, 2018], Evhen Kharkovschenko [Kharkovschenko, 2], Oleg Bazaluk [Bazaluk, 2017], Iryna Liashenko [Liashenko, 2018; Nelipa et al., 2018], etc. The author also used the experience of teaching the course of the History of Ukrainian Philosophy for students of the University of Zielona Gora within the framework of the program of academic exchanges Erasmus + KA107 (Staff Mobility for Teaching) and the experience of working with the professors of the University of Zielona Góra Roman Sapeńko [Rudenko et. al., 2018] and Tomasz Mróz [Mróz, 2018].

\section{Teaching Methodology of the History of Ukrainian Philosophy}

\section{Teaching model of the introductory part}

In the introductory part of the course, it is recommended to explain that every National Philosophy is being considered as a part of National Culture. Students must understand that the Philosophy in its very nature is a part of culture and could be considered as generalization of cultural practices though the theoretical concepts and, of course, reflection. Philosophy is always national and it could not exist separately from being of certain people or nation. Furthermore, sometimes philosophy could turn culture to become national. However, national philosophy could sometimes have a value not only for the culture of its origin, but for other cultures as well. For instance, it happened with Ancient Greek philosophy.

There are no doubts that philosophy is a part of Ukrainian culture. Therefore, it reflects the main cultural practices of Ukrainian people, to be more precisely, their Worldview. That is why studying national philosophy and its history is also a way of learning culture.

It is obvious that not only original ideas or ideas that have national origins might be significant for the development of culture. For instance, the subject of history of Ukrainian philosophy embraces philosophical ideas, conceptions, studies, schools, theories directions and movements that functioned in history and contemporary Ukrainian culture. What is important is the fact that historical and national originating of philosophical ideas does not matter. As well as does not matter originality of philosophical ideas which are considered in the history of Ukrainian philosophy. In other words, the history of Ukrainian philosophy studies value of certain philosophical idea, school, direction, movement or personality for the development of Ukrainian culture.

\section{Teaching model of Periodization}

In University course, it would be optimal to show that History of Ukrainian philosophy has two main periods: pre-national and national. 
The first one represents development of philosophical thought in Ukrainian culture in prenational form (from the time of Kyivan Rus' until $19^{\text {th }}$ century). The second one (from the $19^{\text {th }}$ century to our days) indicates the period in historical development of Ukrainian philosophical culture while which it has been developing correspondingly to the needs of national promotion.

More precisely, we may highlight the following periods in the History of Ukrainian philosophy:

a) Philosophical thought of Kyivan Rus'.

b) Philosophical thought of the Early Modern period.

c) Separate phenomenon of Ukrainian philosophical thought is Philosophy of Gregory Skovoroda.

d) Ukrainian academic philosophy of $19^{\text {th }}$ century.

e) Ukrainian non-academic philosophy of $19^{\text {th }}$ century.

f) Philosophical thought in Ukraine in Soviet and Post-Soviet period.

g) Philosophical thought of Ukrainian diaspora.

\section{Teaching model of Philosophy in Kyivan Rus'}

In the development of Philosophical thought of Kyivan Rus' the key personality is Hilarion. In his the most known work the Sermon on Law and Grace Hilarion made philosophical analyses of the place of Kyivan Rus' in the World history and culture.

Hilarion's philosophical views represent such specific trait of Kyiv Christianity as the Sophia. It is a complex image that represents beliefs about salvation through the practice of social life opposite to religious ascetic practices. The last was more widespread in Byzantine tradition of Christianity. This tradition was supported in Kyivan Rus' by Theodosius from the Kyiv Caves Monastery.

According to Evhen Kharkovschenko, the meaning of the opposition "Sophia - Wisdom", according to which the world is not just God's creation, but also has as its ground a special "Divine origin" — "the soul of the world" [Kharkovschenko, 2010]. "Sophia" is instance that is in-between the Creator and creature, it is a source of divine energy, supplies moving up and moving down. Via Sophia's incarnation nature, the world, the nature and person are (as if) allowed inside Divinity, inside Trinity. Divinity and Trinity accept the world inside and at the same time represent themselves in the world. Thus, the gap between creature, that is a task of God, and salvation, that is the need of mankind, the gap which is characteristic in Roman and Byzantine Christianity is overcome. Philosophical culture of Kyivan Rus' Kyiv Christianity overcomes this gap due to the Sophia approach. Trust and salvation are grounded on active religious life, which is continuation of creating, opposite to ascetic-monastic contemplation and logically reasoned constructions. The mentioned is a main essential difference between philosophical culture of the Kyivan Rus' and Byzantine model of Christianity.

\section{Teaching model of Philosophical thought of the Early Modern Period}

The development of Humanistic and Reformation ideas in Ukrainian culture of $15^{\text {th }}-17^{\text {th }}$ centuries took place in close connection with Polish culture.

Humanism is represented by such thinkers as Gregory of Sanok (Grzegorz of Sanok) (1406-1477), Yuriy Drogobych (Kotermak), Paul Krosnenskyy (Rusin from Krosno) (about 1470-1517), Lucas of New Town (? - About 1542), Stanisław Orzechowski-Roksolan (1513- 
1566), Joseph Vereschynskyy (1532-1598) Sevastyan Klenovich Fabian (about 1545 — about 1602), Shimon Šimonović (Simon Symonid) (1558-1629), Simon Pekalid (Penkalskyy), Ivan Dombrowski (end of $16^{\text {th }}$ - early $17^{\text {th }}$ century.).

They were pioneers of humanistic culture in Poland and Ukraine. Almost all of them, after the education in Western Universities, were operating in Western Ukraine, in Poland "Ruska province", where, in addition to many Western Ukrainian cities, also were included Przemysl, Holm, Jaroslaw, New City, Krosno, Rzeszow, Sanok.

All these thinkers were naming themselves "russins" but at the same time, they appear to be figures in Polish culture, and all of them were adhered to the Catholic faith. Volodymyr Lytvynov headlines this stage in the development of Polish-Ukrainian philosophical culture by the term "Catholic Rus" [History of Ukrainian Philosophy, 2008].

According to Serhii Yosypenko, the main problems of this period was the separation of religious and political discourse, rethinking the "old" and "new" [Yosypenko, 2008]. These problems were typical for such phenomena of Ukrainian culture of the time as polemical literature, fraternal movement.

In the first place, within this period comes out political philosophy. The most interesting for the studying personalities of this time are Dmytro Tuptalo, Stefan Jaworski, and Innocent Gizel.

\section{Teaching model of Gregory Skovoroda's Philosophy}

Gregory Skovoroda (1722-1794) is one of the most generally respected person in the historical and cultural Ukrainian development. According to Dmytro Chyjevskiy, "the life of Skovoroda is his philosophy, and his philosophy is his life". Grasping the sense of life and directing of all the philosophy of Gregory Skovoroda are meant in his words: "The world tried to capture me, but didn't succeed".

Philosophical position of Gregory Skovoroda does not fit into the general context of the Early Modern period.

The main intention of Gregory Skovoroda is a search for genuine sense of Christianity, based on philosophical doubt about "official" Christianity. In the center of philosophical views of Gregory Skovoroda is anthropological mystical teaching about possibility of playing back the unity of man and God within the terrestrial life (dialogue "Narcissus, or know yourself'), teaching about essential dual nature of world, mystical teaching about happiness and "affinity".

Gregory Skovoroda's philosophy represents the Worldiew of Ukrainian culture. Philosopher metaphorically speaking was the son of his time, which was the time of Rationalism and Enlightenment. He refuses to think of philosophy as science, insists on its functioning for person, and opposes "heart" with rationality. Philosophy of Gregory Skovoroda became the basis for the development of a whole direction of religious philosophy in Ukraine and Russia (Pamphil Yurkewich, Vladimir Solovyov, Nikolai Gogol, Fyodor Dostoevsky, etc.).

\section{Teaching model of the Ukrainian Philosophy of $19^{\text {th }}$ century}

Ukrainian academic philosophy of XIX century develops together with such educational centers University of Kharkiv, Emperor's University named after St.Volodymyr in Kyiv, Kyiv Orthodox Academy and University on Odessa in Odessa city. 
There were several intellectual movememts in Ukrainian academic philosophy of $19^{\text {th }}$ century:

a) The Historical systematic school of religious philosophy in Kyiv Orthodox Academy (Vasyl Karpov, Pamphil Yurkewich, etc.).

b) Romanticism in University of Kharkiv (Johann Shad, Ivan Ryzhskiy).

c) Hegelianism, neo-kantianism and positivism in Emperor's University named after St.Volodymyr in Kyiv (Orest Novitsky, George Chelpanov Vladimir Lesevych, Alexiy Gilyarov).

Among the main directions of development of Ukrainian non-academic philosophy of the $19^{\text {th }}$ century can be considered the Populists (Mykola Kostomarov, Panteleimon Kulish, etc.), the Anti-populists (Ivan Franko, Mykhailo Drahomanov, Volodymyr Antonovych, etc.). The Populists and Anti-Populists differed in their visions of driving forces and values of national culture creation and Ukrainian state creation.

The Populists saw the foundation of the national identity development in the practice of preserving of samples of national (ethnic) culture whereas the Anti-Populists believed that the foundation of national culture development in the formation of supra-ethnic (meta-national) elites and, therefore, supra-ethnic values.

\section{Teaching model of the Ukrainian Philosophy of $20^{\text {th }}$ century}

Inside the development of Ukrainian Soviet philosophical culture there should be highlighted such individuals as Peter Demchuk, Vlolodymyr Yurynets, Viktor Petrov (Domontovych), etc. Some scholars believe that in Soviet Ukraine were established the Kyiv School of Philosophy. The founders of the Kyiv School of Philosophy were Pavlo Kopnin, Volodymyr Shynkaruk, Anatoliy Canarskiy, etc.

However, it is very important to remember that Arts and Humanities, especially Philosophy, in Soviet State were under the pressure of Soviet totalitarian ideology, which called as the Marxists-Leninist philosophy. This fact is the reason for avoiding the final conclusions concerning the original philosophical schools in Soviet Ukraine.

Completely different was political and cultural situation of the Ukrainian Diaspora, which was independent from Soviet totalitarian ideology. The key issues of philosophical thought of Diaspora are political philosophical studies, directed to revival of Ukrainian statehood and national culture (Vyacheslav Lypynskiy, Dmytro Dontsov, Ivan Lusyak-Rudnytsky, Mykola Shlemkevych, Alexander Kulchytsky, etc.). In addition, there were investigations in the field of Ukrainian history of philosophy and culture (Dmytro Chizhevsky, Ivan Ogienko, Myroslav Semchyshyn, etc.).Touchstones for the scholars of the Ukrainian Diaspora were issues of mental traits of Ukrainian nation, problems of its ethnical genesis and interdisciplinary studies of Ukrainian culture.

After Ukraine had gained an Independence, Ukrainian philosophical culture face faced typical problems for post-totalitarian society, which is simultaneous to Education and Science. Among them, we may notice long-term actual isolation of Ukrainian science from the World, insufficient material and technical base and unsatisfactory level of financing, high level of scholars' emigration. 


\section{Evaluation Methodology of the Learning Outcomes}

In our opinion, the assessment of the results of the course students' study of the History of Ukrainian Philosophy should be based on the following competencies, which could be considered as assessment criteria:

1. Ability to carry out historical and philosophical descriptions and systematization of philosophical ideas, currents, schools, directions that functioned at different historical stages of the development of Ukrainian culture.

2. Ability to read and analyze original works (undated texts) belonging to the Ukrainian philosophical culture, the ability to determine their content, main problems, belonging to a certain historical stage of development of Ukrainian culture.

3. Ability to independently and with high degree of fluency determine and disclose the content of the main historical stages of development of Ukrainian philosophy, basic philosophical ideas, trends, schools, directions, concepts and problems.

4. Ability to independently determine the affiliation / inadequacy of the work and its author to a certain historical stage, current, school, direction of Ukrainian philosophical culture.

5. Ability to autonomously with a high degree of fluency to disclose, in oral or written form, the content, structure, main ideas and problems of the key to the development of the Ukrainian culture of philosophical works, to establish their connection with the historical sociocultural context and philosophical biography of the author.

6. Ability to write in Ukrainian language small volume of abstract and analytical works in the field of history of Ukrainian philosophy.

7. Ability to reproduce the philosophical biography of the most influential and significant representatives of Ukrainian philosophical thought, the ability to write in Ukrainian, small in scope of biographical descriptions of the creativity of Ukrainian thinkers of the past.

8. Ability to carry out rational reconstruction of philosophical problems, ideas, doctrines, concepts, trends, directions of the history of Ukrainian philosophy, ability to determine the conditions for using the achievements of the Ukrainian philosophical thought of the past to solve the most important problems of the development of contemporary Ukrainian culture, philosophy and humanities.

\section{Conclusions}

Teaching Methodology of the History of Ukrainian philosophy is based on understanding Philosophy as a functional part of the National culture. Therefore, the course on the History of Ukrainian philosophy is supposed to be divided in two main parts. The first one covers pre-national period of Ukrainian culture and the second one embraces the national period. Furthermore, historical and national originating (and originality) of philosophical ideas, which are functioning in Ukrainian culture, does not matter for History of Ukrainian philosophy. All of them are covered by its research field. Among the variety of periodization approaches, which present in contemporary scholar literature on the History of Ukrainian philosophy, the most appropriate includes 6 main periods from Kyivan Rus' up to Soviet and Post-Soviet Times. In addition, the peculiarity of the teaching model of periodization of the History of Ukrainian philosophy is that the Philosophy of Gregory Skovoroda should be considered 
separately, regardless the Baroque and the Enlightenment movements in Ukrainian culture.

The Evaluation Methodology of the learning outcomes on the History of Ukrainian philosophy course is grounded on eight main competencies that could be divided in two groups. The first group describe historiographical abilities whereas the second one reflects abilities concerning the rational reconstruction. Combination of these two groups of competencies makes the Evaluation Methodology clear, flexible and representative.

\section{References}

Bazaluk, Oleg. The Strategies of Systematization of the Theories of Education. The Main Meaning and Features of the Theories of Education of Plato's and Isocrates' Lines. Future Human Image, Vol. 7, 2017: 11-27.

History of Ukrainian Philosophy. Student's book. [Rusin M.Y., Ogorodnyk I.V., Bondar S.V., etc.]. Kyiv: Kyiv University Press, 2008.

Kharkovschenko, Evhen. Sophiiology of Kyiv Chrisitianity. Kyiv, 2004.

Liashenko, Iryna. Wilhelm Dilthey: Understanding the Human World. Philosophy and Cosmology. Vol. 20, 2018: 163-169. DOI: 10.29202/phil-cosm/20/16

Liashenko, Iryna and Sergii Rudenko. The Management Features of the University Preparatory Department. Scientific Bulletin of National Mining University. Vol. 1, 2018: 132-138. DOI: $10.29202 /$ nvngu/2018-1/6.

Nelipa, Dmytro, Oleg Batrymenko, Sergii Rudenko and Iryna Liashenko. Higher education management in Ukraine: will generation change help us transform it faster? Scientific Bulletin of National Mining University. Vol. 3, 2018: 167-175. DOI: 10.29202/ nvngu/2018-3/19

Mróz, Tomasz. Reply to the Paper "National Philosophy as a subject of Comparative Research". Sententiae, Vol.37(1), 2018: 130-135. DOI: 10.22240/sent37.01.130

Mróz, Tomasz. Selected issues on the History of Polish Philosophy. Vilnius, Vilnius University, 2016.

Rudenko, Sergii, Roman Sapeńko, Oleg Bazaluk, and Vadym Tytarenko. Management Features of International Educational Projects between Universities of Poland and Ukraine. Naukovyi Visnyk Natsionalnoho Hirnychoho Universytetu. 2, 2018: 142-147. DOI: 10.29202/nvngu/2018-2/21

Yosypenko, Serhii and Rudenko, Sergii. National Philosophy as a subject of Comparative Research. Sententiae, Vol.37(1), 2018: 120-129. DOI:10.22240/sent37.01.120

Yosypenko, Serhii. Towards the origin of Ukrainian modernity. Kyiv, 2008. 